\title{
Postlarval settling behavior, substrate preference, and time to metamorphosis for red king crab Paralithodes camtschaticus
}

\author{
Bradley G. Stevens ${ }^{1, *}$, Jiro Kittaka ${ }^{2}$ \\ 'National Marine Fisheries Service, Alaska Fisheries Science Center, Kodiak Laboratory, PO Box 1638, \\ Kodiak, Alaska 99615, USA \\ ${ }^{2}$ Research Institute for Marine Biology, Tokyo Science University, Onnemoto 168, Nemuro, Hokkaido 087-01, Japan
}

\begin{abstract}
Swimming behavior was observed and substrate preference determined for glaucothoe stage postlarvae of the red king crab Paralithodes camtschaticus in the laboratory. One hundred $1 \mathrm{~d}$ old glaucothoe were placed into each of 3 replicate $10 \mathrm{l}$ aquaria, each containing a choice of 3 substrates: sand, gravel, or synthetic fiber mesh. Glaucothoe began settling on the first day, and $<10 \%$ remained swimming after Day 6. Glaucothoe showed a significant preference for the structurally complex mesh substrate. Occupancy of mesh increased from $49 \%$ on Day 2 to $75 \%$ by metamorphosis to the first crab (C1) instar, with a mean of $62 \pm 11 \%$. Glaucothoe rejected sand, and only $1 \%$ were observed on it. Settlement was also tested in aquaria with only sand, gravel or mesh substrates. Glaucothoe in gravel- or mesh-only ađuluria settled rapidly. Whereas $40 \%$ of glaucothoe in the sand-only aquarium continued swimming until metamorphosis to $\mathrm{C} 1$ instar. In addition, mean time-to-metamorphosis in the sand-only aquarium (17.6 d) was significantly greater than in other experimental aquaria (16.8 d). Glaucothoe in the sand-only aquarium exhibited marked diumal swimming behavior; $66 \%$ were swimming at $14: 00 \mathrm{~h}$ (vs a maximum of $12 \%$ in other aquaria), but only $5 \%$ (vs $1 \%$ ) were swimming at 02:00 h. Daytime swimming probably allows glaucothoe to avoid nocturnal predators while searching for preferred substrates, i.e. those which are structurally complex, can be easily grasped, and provide a high degree of interstitial space.
\end{abstract}

KEY WORDS: Settling - Metamorphosis $\cdot$ Substrate $\cdot$ Decapoda $\cdot$ Postlarvae $\cdot$ Glaucothoe

\section{INTRODUCTION}

The behavior of decapod larvae has significant effects on their spatial and temporal recruitment patterns. Planktonic (zoea) stages of decapod larvae exhibit directional movement in response to physical stimuli such as light (Forward 1974, Shirley \& Shirley 1988), salinity (Forward 1989a, b), hydrostatic pressure (Forward et al. 1989), temperature (Forward 1990), gravity (Sulkin et al. 1980), and currents (Shirley \& Shirley 1988). Studies on spiny lobster Panulirus argus (Herrnkind \& Butler 1986), blue crab Callinectes sapidus (Lipcius et al. 1990), and American lobster Homarus americanus (Wahle \& Steneck 1991) have

\footnotetext{
·E-mail: bradley.g.stevens@noaa.gov
}

indicated that critical choices about benthic habitat are made during the settlement of postlarval stages. Tidal and/or diurnal synchronization of swimming behavior (Cronin \& Forward 1979, Tankersley \& Forward 1994, Zeng \& Naylor 1996) and/or metamorphosis (Forward et al. 1996, Zeng et al. 1997) also plays a role in delivering decapod larvae to appropriate benthic habitats.

The red king crab Paralithodes camtschaticus is a commercially important species of anomuran crustacean found in Alaska, Russia, and Japan. Red king crab develop through 4 zoeal stages, followed by a postlarval (glaucothoe) stage, before metamorphosis to the first juvenile crab (C1) stage (Sato \& Tanaka 1949). Settling occurs during the glaucothoe stage. The abundance and survival of planktonic king crab larvae and postlarvae have been studied in the field (Paul et al. 
1989, Shirley \& Shirley 1989a, b, c, Paul \& Paul 1990)، and much work has been conducted on aquaculture conditions (Nakanishi 1981, 1987, 1988). However, behavior of the glaucothoe stage, and its role in settling and recruitment processes, remain largely unknown (Tyler \& Kruse 1996).

Young-of-the-year (YOY) red king crab and juveniles of age $1+$ have been found in contact with seastars (Dew et al. 1992) as well as sponge and bryozoan colonies (Sundberg \& Clausen 1977), hydroid and mussel colonies, stalked ascidians, and polychaete tubes (Stevens \& MacIntosh 1991), and among shell debris and cobble (McMurray et al. 1986). These habitats are important until about 1.5 yr of age, when red king crab start to exhibit aggregative (podding) behavior (Powell \& Nickerson 1965, Dew 1988). The scarcity of biological structures in some regions of the crab's range, such as the Bering Sea, suggests that the distribution of early juvenile crabs arises due to either (1) indiscriminate settlement, followed by low survival of those which settle in open versus structured habitats, or (2) a behavioral preference for settlement in specific cryptic habitats. The latter hypothesis is supported by observations that YOY red king crab exhibit a preference for bryozoan and hydroid colonies when given a choice (Babcock et al. 1988), and observations that red king crab glaucothoe will settle in large numbers on various types of artificial collectors (Freese \& Babcock 1990, Blau \& Byersdorfer 1994). However, no directed study of glaucothoe settlement has been made to date, either in the lab or the field.

This study was conducted to determine whether red king crab glaucothoe exhibit a preference between selected substrate types, and to define more clearly the nature of swimming, settling behavior, and substrate utilization by glaucothoe. All work was conducted at the Research Institute for Marine Biology, Nemuro, Hokkaido, Japan. The experiments were designed to test the following specific null hypotheses: (1) glaucothoe exhibit no preference between 3 substrates of differing texture; (2) proportions of glaucothoe swimming do not differ between day and night; (3) substrate choice has no effect on time-to-metamorphosis of glaucothoe.

\section{METHODS AND MATERIALS}

The experimental apparatus consisted of 7 clear plastic rectangular $10 \mathrm{l}$ aquaria $(33 \times 18 \times 22 \mathrm{~cm})$. Three aquaria (referred to as mixed substrates) each contained 3 polypropylene trays $(9 \times 15 \times 5 \mathrm{~cm})$ with a different substrate. Each tray had thirteen $2 \mathrm{~mm}$ drainage holes in the bottom, covered with $0.5 \mathrm{~mm}$ nylon netting attached with silicone sealant, and was supported by four $12 \mathrm{~mm}$ plastic legs. Trays and sealant were allowed to cure from 4 to $14 \mathrm{~d}$, then were soaked in seawater $24 \mathrm{~h}$ prior to use. Each tray contained one of 3 possible substrates: course dark gray sand $(0.2$ to $0.4 \mathrm{~mm}$ diameter), white quartz granules ('gravel'; $72 \%$ was between 2 and $4 \mathrm{~mm}$ diameter), or synthetic fiber mesh. The mesh was a $25 \mathrm{~mm}$ thick mat of $0.3 \mathrm{~mm}$ diameter tangled monofilament aquarium filter material, of neutral color, cut to fit inside the trays. Mesh was similar in structure to the 'hog's hair' material used as postlarval collectors for Callinectes sapidus by Van Montfrans et al. (1990). Both sand and gravel were autoclaved to kill microbiota, then placed in a $1 \mathrm{~cm}$ deep layer in the experimental trays (mesh could not be autoclaved without destroying it). Because the surface of each substrate was 2.5 to $4 \mathrm{~cm}$ below the upper lip of the tray, glaucothoe could enter the trays only by swimming; they could not crawl from one substrate to another. The trays were placed in a Latin-square arrangement, so that each substrate occurred in a different position (left, center, or right) in each tank. An airstone was placed on the bottom of each tank, outside the trays, near the center of one side wall.

Three aquaria contained only a single substrate, sand, gravel, or mesh, covering the bottom. All 6 experimental aquaria were filled with filtered $(10 \mu \mathrm{m})$ seawater ( $34 \mathrm{ppt}$ ) to a depth of $18 \mathrm{~cm}$, and partially submerged side by side in a water bath at ambient temperature, which increased from 8.3 to $12.0^{\circ} \mathrm{C}$ (mean $10.6 \pm 1.3^{\circ} \mathrm{C}$ ) during the course of the experiment. As a survival control for the experiment, another aquarium (\#7) was prepared with no substrates except the airstone. However, due to space limitations, it was placed in a separate water bath at a lower temperature $\left(8.5 \pm 1.0^{\circ} \mathrm{C}\right)$. A fluorescent light fixture and a southeast facing window were 2.5 and $5 \mathrm{~m}$ away from, respectively, and parallel to the aquaria, so all substrates (in mixed aquaria) were equidistant from the light. In order to stabilize water temperatures from daily changes), and provide a more natural light regime, all 6 experimental aquaria were kept covered with a $3 \mathrm{~cm}$ thick styrofoam cover, and were uncovered just prior to counting on each day (except during diel observations, see below).

Larvae were hatched from wild-caught female red king crabs on 17 April 1996, placed into a $150 \mathrm{l}$ tank, and fed a combination of Artemia nauplii and diatoms (Thalassiosira sp.). On the date of metamorphosis from the last zoeal stage (Day 0, 14 May 1996), 100 glaucothoe were transferred to each of the 6 experimental aquaria and the control aquarium with a large bore pipette, and released $3 \mathrm{~cm}$ below the water surface in the center of each aquarium. The number of swimming glaucothoe in all experimental aquaria was counted $2 \mathrm{~h}$ after introduction into the aquaria, and daily there- 
after. Survival (but not swimming behavior) was assessed daily in the control aquarium. Starting on Day 2, and every 2 or $3 \mathrm{~d}$ thereafter, all trays were removed from each aquarium, the numbers of glaucothoe on each substrate were counted, mortalities were removed, and all trays and glaucothoe were transferred to clean aquaria with fresh seawater. Glaucothoe on sand and gravel substrates were not removed, but simply transferred in the trays. Glaucothoe in the mesh substrate were removed by shaking the mesh inside a container of clean seawater. They were then counted, placed back onto the mesh, and replaced into the tray. Glaucothoe in 'other' locations, including the outside of the trays, the bottom of the tank, or the airstones, were considered to have no substrate preference. After returning the experimental aquaria to the water bath, all swimming and 'other' glaucothoe were released in the center of the appropriate tank, $3 \mathrm{~cm}$ below the water surface. When metamorphosis to the C1 instar began, aquaria were monitored daily for molts and mortalities. Time-tometamorphosis (TTM) was determined to the nearest day for each glaucothoe which molted to $\mathrm{C} 1$, and average TTM was calculated for each aquarium. The experiment was conducted until all glaucothoe had molted to the first crab stage or died. Glaucothoe were not fed during the experiment, since they do not feed (Nakanishi 1988).

Diel behavior of glaucothoe was observed over $48 \mathrm{~h}$. Starting at 10:00 h on 25 May (Day 11), the number of swimming glaucothoe was counted in each aquarium every $4 \mathrm{~h}$. Counts during dark hours were made quickly using a dim light source. During this period, all aquaria remained uncovered and exposed to ambient light. Natural photoperiod was 15.5: $8.5 \mathrm{~h}$ L:D (see below, and Fig. 6); this was augmented by artificial lighting between 08:30 and 18:00 h.

Potential toxicity of the mesh substrate was tested prior to starting the experiment, using glaucothoe (from a previous hatch), with weekly water changes. Survival to stage $\mathrm{C} 1$ of 38 glaucothoe in an aquarium containing only a polypropylene tray (59\%) was not significantly different $(Z=0.472$ ) from survival in an aquarium with a tray and a piece of mesh (66\%) (Z-test for 2 proportions, corrected for continuity; Zar 1984).

Separate chi-squared tests were conducted on the data from each aquarium and date of observation. Only counts of glaucothoe which were ob- served on the 3 test substrates were included, and expected values were one-third of the total on those substrates. The null hypothesis was that no substrate preference occurred. Within each tank, a pooled chisquared was also calculated from data summed over all dates of observation. Heterogeneity chi-squared values were calculated as the difference between the pooled tests and the sums of individual tests, and indicate whether the data were homogeneous across time, thus whether the pooled results are usable. A G-test (Zar 1984) was used to test for differences in survival of red king crab glaucothoe among aquaria with different substrate types. TTM (to stage C1) for glaucothoe on different substrate types was compared by analysis of variance (ANOVA) after testing for homogeneity of variances. Post-hoc comparisons were conducted using Tukey's honestly significant difference (HSD) test, using $\alpha=0.05$ as the experiment-wise error rate. Average values are given as mean \pm SD (standard deviation).

\section{RESULTS}

\section{Swimming and settling behavior}

Glaucothoe began to settle immediately after being placed in the experimental aquaria. The proportion of swimmers in aquaria with mixed substrates was $28 \%$ on Day 0 and Day 3, and declined to $<10 \%$ by Day 7 . but some $(<5 \%)$ were still swimming until Day 17 (Fig. 1). Only $1 \%$ of glaucothoe in the mesh aquarium were still swimming by Day 2, but the proportion then

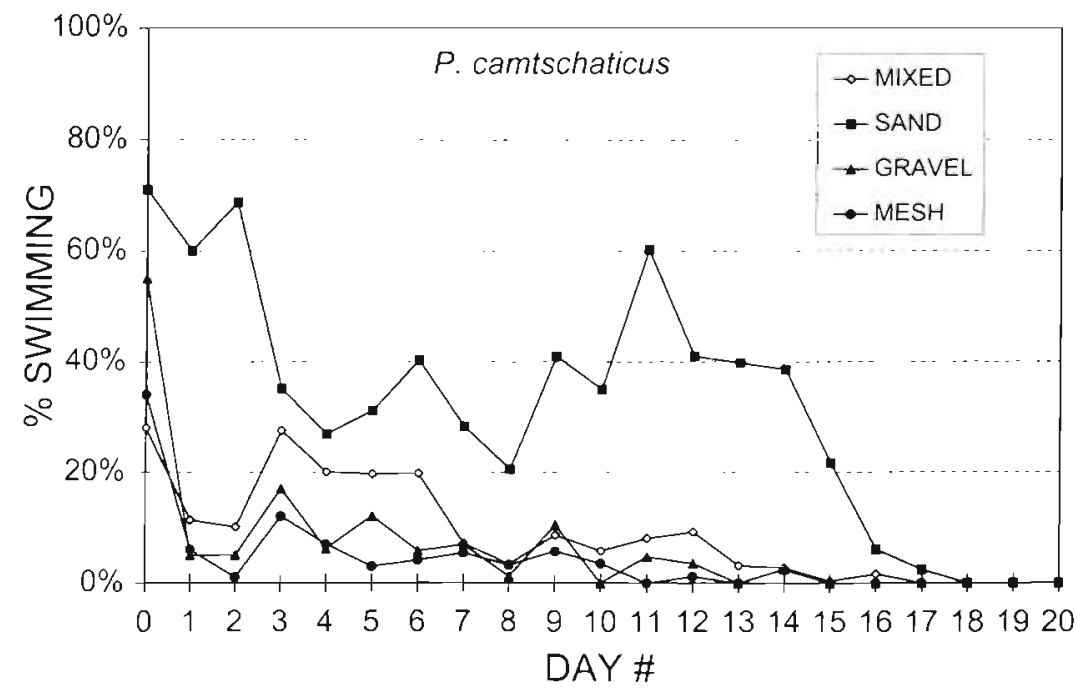

Fig. 1. Paralithodes camtschaticus. Percent of red king crab glaucothoe swimming on each day of observation. 'Mixed' represents the mean of 3 aquaria, each containing 3 trays of different substrates. 'Sand', 'gravel', and 'mesh' represent aquaria with only 1 substrate 


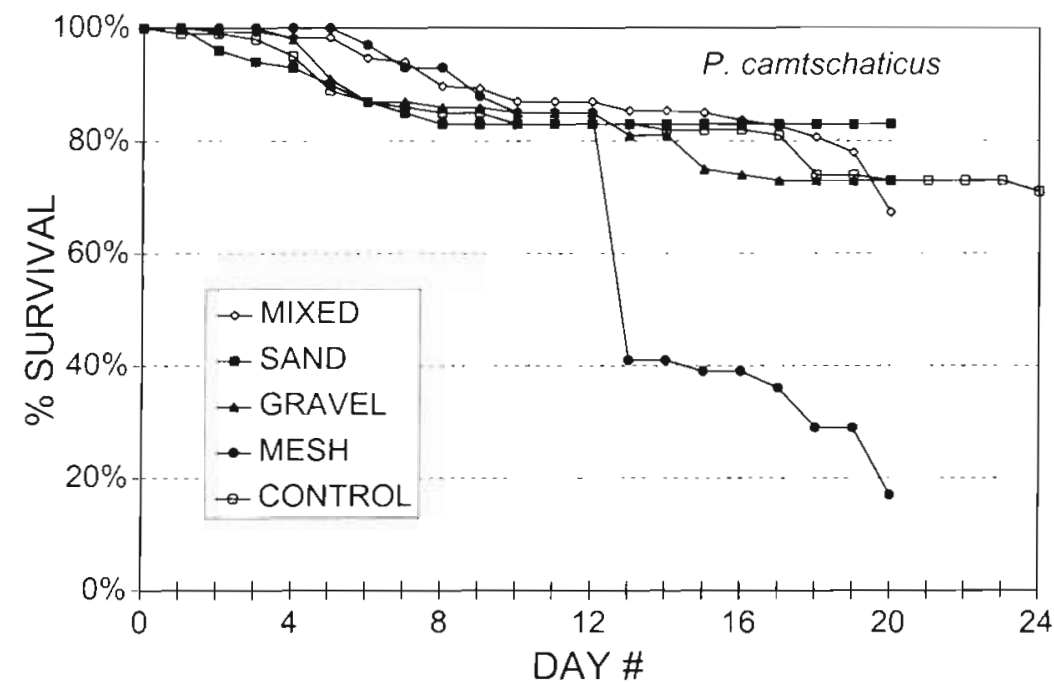

Fig. 2. Paralithodes camtschaticus. Survival of red king crab glaucothoe in aquaria with sand, gravel, mesh, or mixed substrates

at Day 11 (the beginning of the diel study), after which it gradually declined to $0 \%$ on Day 18 , as metamorphosis to C1 occurred.

\section{Glaucothoe survival and time-to- metamorphosis}

Survival of glaucothoe to stage C1 in the aquaria with sand $(83 \%)$, gravel $(73 \%)$, and mixed substrates $(67 \%)$ did not differ significantly $(G=7.5, \mathrm{p}>0.05$, $\mathrm{df}=3$ ) from survival in the control aquarium ( $71 \%$ ) (Fig. 2). Survival of those in the mesh-only aquarium was similar (>80\%) until Day 13 at which time half were found dead, and only $17 \%$ survived to stage C1. Variances of TTM for experimental glaucothoe were homogeneous (Levene statistic $=2.032, p>0.10)$,

fluctuated around $5 \%$ until Day 11 , after which 0 to $1 \%$ were swimming. The proportion of swimmers in the gravel aquarium fluctuated between 1 and $10 \%$ until Day 10 , then declined to $0 \%$ by Day 15 . In contrast, many glaucothoe in the sand aquarium did not settle until the last few days before molting. The proportion of swimmers in the sand aquarium was $70 \%$ on Day 0 , declined to $21 \%$ by Day 8 , then increased to $60 \%$

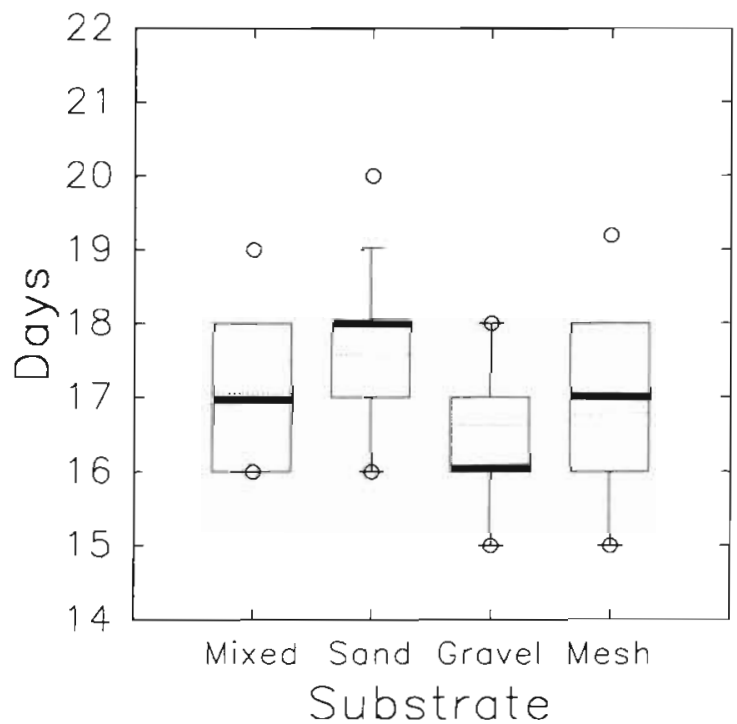

Fig. 3. Paralithodes camtschaticus. Box plot of time-to-metamorphosis (TTM) for red king crab glaucothoe in sand, gravel, mesh, or mixed substrate aquaria. TTM was significantly longer in the sand aquarium than in any others. Parts of box are median (thick line), mean (dotted line), 25th/75th percentiles (bottom and top of box), 90th/10th percentiles

(T-bars), and 5th/95th percentile (open circles) allowing use of ANOVA. Mean TTM differed significantly $(F=9.97, p<0.001)$ between aquaria, and was significantly greater in the sand aquarium $(17.6 \pm 1.2 \mathrm{~d}, \mathrm{n}=$ 76) than in aquaria with gravel $(16.6 \pm 1.1 \mathrm{~d}, \mathrm{n}=73)$, mesh $(16.8 \pm 1.4 \mathrm{~d}, \mathrm{n}=18)$, or mixed substrates $(17.1 \pm$ $1.0 \mathrm{~d}, \mathrm{n}=234$ ) (Tukey's HSD test, $\mathrm{p}<0.05$ ) (Fig, 3). Mean

Table 1 Paralithodes camtschaticus. Chi-squared analysis of glaucothoe settling locations for red king crab. Numbers are $\chi^{2}$ values for all counts in each tank, utilizing only larvae which settled on 1 of the 3 test substrates. All $\chi^{2}$ values exceeded the critical value of $5.991_{2, \alpha=0.05}$, indicating that larvae did not settle on all 3 substrates in equal proportions, within any date or aquarium. The pooled $\chi^{2}$ was calculated across all dates of observation. Heterogeneity $\chi^{2}$ values are the difference between the sum of individual tests and the pooled test; significant values indicate that the results were not homogeneous over time. Critical values ( $\chi^{2}$ crit.) shown are for $\alpha=0.5$. ns: not significant

\begin{tabular}{ccccc}
$\begin{array}{c}\text { Observation } \\
\text { no. }\end{array}$ & $\begin{array}{c}\text { Aquarium } \\
1\end{array}$ & $\begin{array}{c}\text { Aquarium } \\
\text { Aquarium }\end{array}$ & df \\
\hline 1 & 103.0 & 71.5 & 31.0 & 2 \\
2 & 40.7 & 59.4 & 38.3 & 2 \\
3 & 45.4 & 68.6 & 16.8 & 2 \\
4 & 46.5 & 120.6 & 24.4 & 2 \\
5 & 76.1 & 146.0 & 43.4 & 2 \\
6 & 76.3 & 146.3 & 67.8 & 2 \\
7 & 42.8 & 131.5 & 50.7 & 2 \\
8 & 56.1 & 116.0 & 52.4 & 2 \\
9 & 46.3 & 98.7 & 31.4 & 2 \\
Sum of $\chi^{2}$ values & 533.3 & 958.6 & 356.2 & 18 \\
Pooled $\chi^{2}$ & 515.6 & 948.2 & 324.2 & 2 \\
Heterogeneity & 17.7 & 10.4 & 32.0 & 16 \\
$\chi^{2}$ crit. & 26.3 & 26.3 & 26.3 & 16 \\
Significance & $\mathrm{ns}$ & $\mathrm{ns}$ & $\mathrm{p}<0.01$ & \\
& & \multicolumn{4}{c}{} \\
\end{tabular}




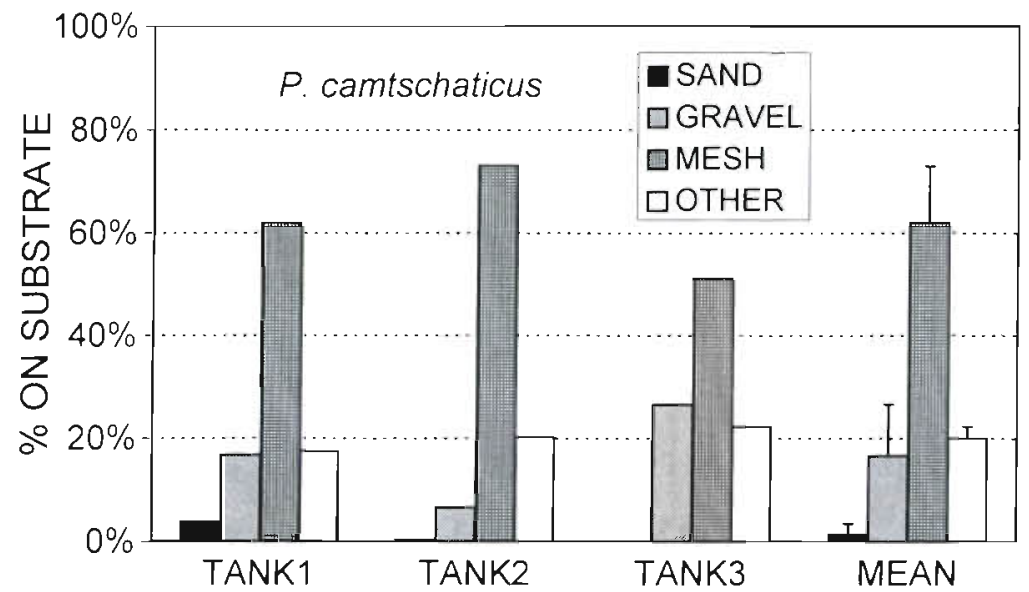

Fig. 4. Paralithodes camtschaticus. Average occupancy of each substrate by red king crab glaucothoe in each aquarium (summed over time), and overall mean (+1 SD) occupancy for each substrate observed to descend into the sand tray, touch the sand, and then swim up and away within a few seconds. Chi-squared values (Table 1) for each aquarium and date of observation (using only the 3 test substrates) were all significant at $\mathrm{p}<0.05$, leading to rejection of the null hypothesis for each observation, i.e. glaucothoe did not settle on all 3 experimental substrates in equal proportions at any time. Heterogeneity chi-squared values were significant only for Aquarium 3, indicating that the data were homogeneous across time in Aquaria 1 and 2, but not in Aquarium 3. Aquarium 3 had a smaller proportion of glaucothoe on mesh, and larger proportions on gravel and other substrates, than Aquarium 1 or 2 (Fig. 4).
TTM for control glaucothoe $(22.5 \pm 1.2 \mathrm{~d})$ was longer, probably due to lower temperature, and was not compared to experimental groups.

\section{Substrate preference}

Glaucothoe showed a clear preference for the mesh substrate, followed by gravel and other locations (Fig. 4). The mean proportions of non-swimming glaucothoe on each substrate were: mesh $62 \pm 11 \%$; gravel $17 \pm 10 \%$; other locations (e.g. on the airstone, or outside of trays) $20 \pm 2 \%$; and sand $1.4 \pm 2.1 \%$ (Fig. 4). The proportion of all glaucothoe on mesh increased from $49 \%$ on Day 2 to $75 \%$ by Day 20 (Fig. 5). The proportion of all glaucothoe observed on gravel ranged from 7 to $20 \%$, with no trend. The proportion of glaucothoe in other locations declined from $33 \%$ on Day 4 to $0 \%$ by Day 20 as they moved onto preferred substrates. The proportion of glaucothoe on sand was $<1 \%$ until Day 16 , when 8 glaucothoe in Aquarium 1 settled on sand, probably due to the onset of metamorphosis. Most glaucothoe observed 'on' mesh actually occupied the interstitial spaces of the mesh, or were underneath it, rather than on its surface. Most glaucothoe in the gravel trays were observed on top of gravel particles, although some were between them. Glaucothoe appeared to reject sand substrates. On several occasions, swimming glaucothoe were

\section{Diurnal swimming behavior}

Red king crab glaucothoe exhibited a well-defined diurnal swimming behavior (Fig. 6). In the sand-only tank, $>40 \%$ of glaucothoe were swimming between 06:00 and 18:00 h, with a peak of $64 \pm 5 \%$ at 14:00 h. Between sunset (18:45 h) and sunrise (03:45 h), swimming decreased dramatically, to a low of $5 \pm 3 \%$ at 02:00 h. There was little variability between the 2 consecutive days, except at 10:00 h. At night, most glaucothoe in the sand-only aquarium were inactive, sitting motionless on the sand, and many were upside down, as if unable to move. Glaucothoe in the gravel-only

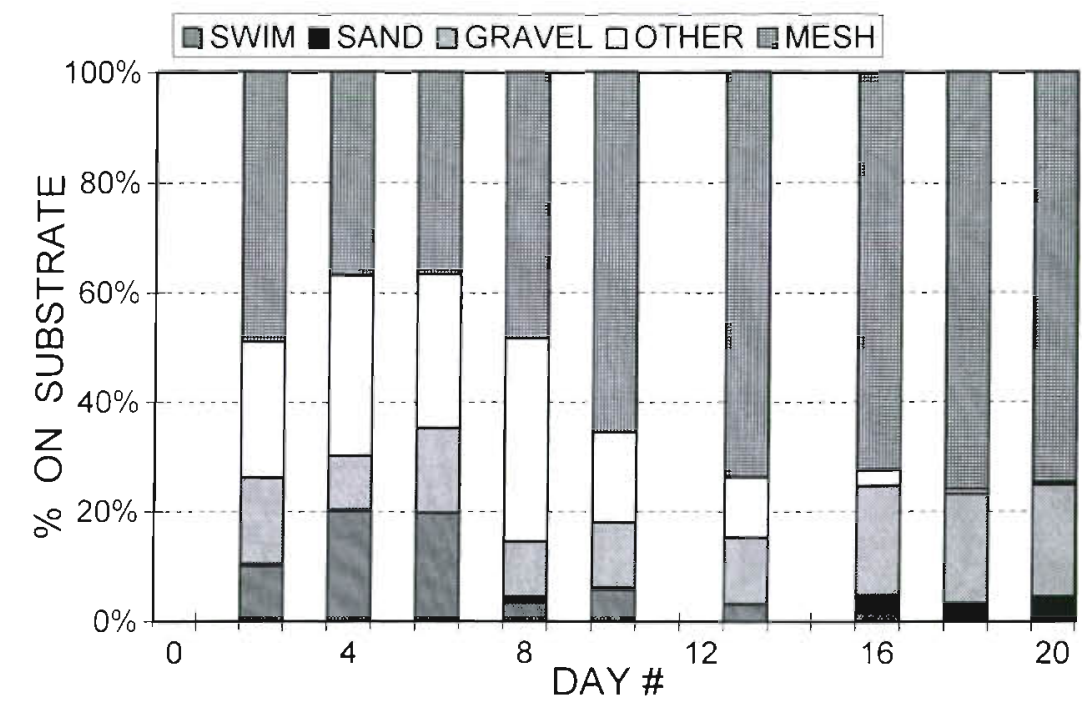

Fig. 5. Paralithodes camtschaticus. Proportions of red king crab glaucothoe on each substrate during each observation (summed across aquaria), showing change over time 
and mixed substrate aquaria also exhibited diumal swimming behavior, but to a lesser degree, with peak activity of about $12 \%$ at $18: 00$ h, least activity ( 0 to $1 \%$ ) at 02:00 h, and greater variability between days. Diurnal activity in the mesh-only aquarium was barely detectable.

\section{General observations on behavior}

Red king crab zoea larvae swim more or less continuously in culture, whereas glaucothoe are highly thigmotactic and use their chelipeds to grasp any substrate within reach. An effective method for capturing and removing them from culture aquaria was to suspend a piece of $0.5 \mathrm{~mm}$ mesh nylon netting in the water. Glaucothoe could grip both gravel and mesh easily, but held onto mesh fibers much more strongly with their legs and chelae, making them difficult to remove. Once glaucothoe settled onto a preferred substrate, they were relatively lethargic and showed little tendency to move. Although individual glaucothoe could not be distinguished, similar (or increasing) counts on mesh on consecutive days suggest that those which had settled on mesh remained there until metamorphosis. However, a small number of glaucothoe were almost always in motion, and as a result, most of those which settled on less preferable substrates (sand or gravel) eventually migrated to a more preferred substrate (mesh) by swimming. Unlike the juvenile and adult stages, glaucothoe are not dorso-ventrally flattened, and are unstable in an upright position unless grasping some part of the substratum

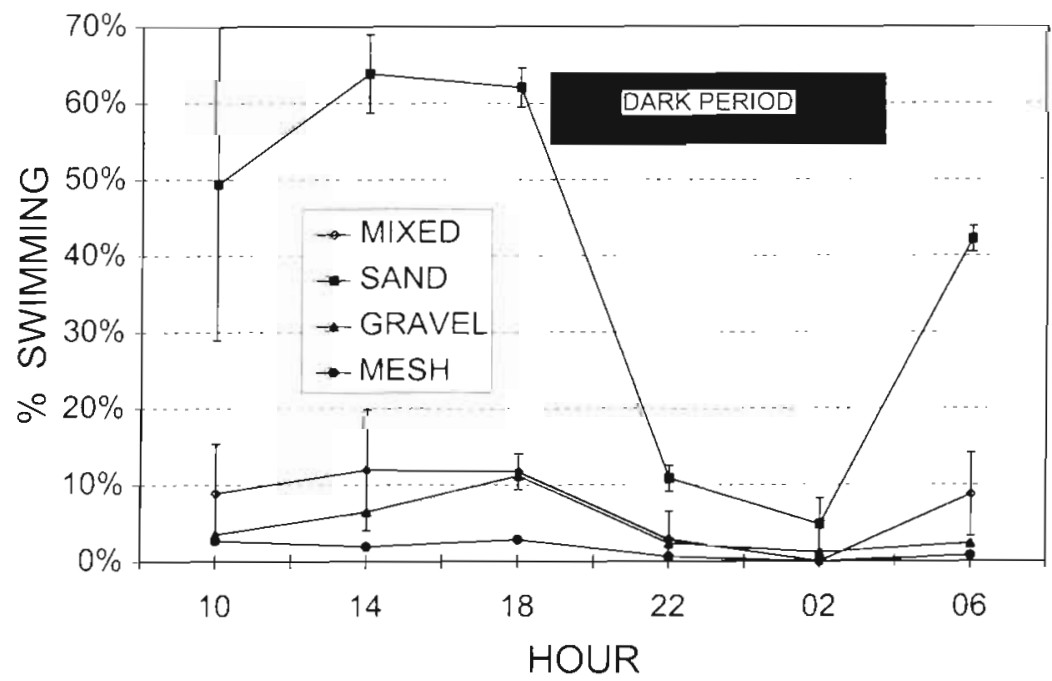

Fig. 6. Paralithodes camtschaticus. Diurnal swimming behavior of red king crab glaucothoe, averaged over $2 \mathrm{~d}$. Peak activity occurred between 14:00 and 18:00 $\mathrm{h}$ in all aquaria, but was much greater in the sand-only aquarium than in other aquaria. Sunset occurred at 18:4.5 h; sunrise at 03:45 h. For convenience, error bars ( $\pm 1 \mathrm{SD})$ are shown only for sand and mixed substrates

\section{DISCUSSION}

Red king crab glaucothoe actively select substrates for settling, and exhibit a clear preference for complex 3-dimensional structures with interstitial space, in laboratory experiments. When a suitable substrate was available, glaucothoe settled within a few days. However, in the absence of a suitable substrate, many glaucothoe continued swimming, and metamorphosis to stage $\mathrm{Cl}$ was delayed about $1 \mathrm{~d}$ relative to those which had access to preferred substrates. These results indicate that, while there is some endogenous control over TTM, it may also be influenced by exogenous factors such as substrate. The slight but significant $1 \mathrm{~d}$ difference in TTM may be ecologically important, since those glaucothoe which molt sooner gain access to food and refuge resources earlier.

The importance of substrate for metamorphosis of larval invertebrates has been recognized for many years; some species will settle and metamorphose only on specific substrates (see review by Scheltema 1974). Our study is the first to demonstrate substrate selection by settling stages of lithodid crabs, although substrate specificity is exhibited by the postlarval stages of several other decapod species. Pueruli and juveniles of the spiny lobster Panulirus argus settle preferentially on the red algae Laurencia spp., and are never found on open sand (Herrnkind \& Butler 1986). Furthermore, pueruli strongly prefer structurally complex artificial habitats over those which offer no refuge, regardless of food availability, suggesting that '...structural complexity is a major determinant of habitat selection' for $P$. argus (Herrnkind \& Butler 1986). Megalopae of the porcelain crabs Petrolisthes cinctipes and $P$. eriomerus settle gregariously, almost exclusively among adult conspecifics (Jensen 1989). Megalopae of Echinoecus pentagonus, a brachyuran crab symbiotic with sea urchins, are strongly attracted to fresh spines or live urchins of their host species as well as a closely related non-host species, but all megalopae eventually migrate to the host species (Castro 1978).

Duration of the settling postlarval stage in some decapods may be accelerated or delayed by exposure to different environmental cues (see review by Pechenik 1990). Megalopae of the blue crab Callinectes sapidus metamorphose approximately $1 \mathrm{~d}$ earlier in estuarine water than in offshore water, and up to 2 d earlier in estuarine water with eelgrass (Forward et al. 1994). TTM for 
blue crab can also be reduced by the addition of the macrophyte Ulva to offshore (but not inshore) water (Brumbaugh \& McConaugha 1995), and by lowering the salinity of marsh (but not ocean) water (Wolcott \& De Vries 1994). Acceleration of metamorphosis in C. sapidus megalopae is caused by chemical cues from several estuarine plants, but not by structure alone (Forward et al. 1996). Substrates can also reduce TTM; the presence of beach sand causes reduced TTM for the last zoeal stage of the anomuran Emerita talpoida, but not for megalopae (Harvey 1993). Megalopae of the hermit crab Clibanarius erythropus extend their TTM up to $70 \%$ in the absence of gastropod shells (Harms 1992). Natural sediments and seawater overlying a marsh accelerate TTM for fiddler crab Uca pugnax (O'Connor \& Judge 1977) TTM for mud crab Panopeus herbstii, megalopae is accelerated by the presence of natural rock/shell debris and Fucus with natural biofilms, but not by sand or structural mimics without biofilms (Weber \& Epifanio 1996). However, Pechenik (1990) stated that evidence for delayed metamorphosis of marine larvae was much more common in laboratory studies than in field studies, and careful definitions of metamorphic competence were needed to resolve this paradox.

Some decapods exhibit endogenous rhythms of molting and metamorphosis, usually coinciding with tidal or diel cycles. Wild-caught megalopae of the shore crab Carcinus maenas showed persistent circatidal rhythms of molting in the lab, centered around times of expected high tides (Zeng et al. 1997). Adult female C. maenas from precopula pairs also exhibit circatidal molting (Abello et al. 1997). Megalopae of the blue crab Callinectes sapidus metamorphose during daylight hours (Forward et al. 1996). Our observations of behavior and molting were made only once daily, so the periodicity of molting could not be determined on a finer scale.

The settlement patterns exhibited by king crab glaucothoe in our experiment were probably a response to the physical characteristics of the substrates, such as the size of particles or interstitial spaces, rather than to organic components. There should have been few chemical cues on gravel or mesh to induce settlement or metamorphosis. Only sand was of marine origin, which might have been expected to cause increased settlement, if anything. However, it is possible that certain substrates were rejected because they lacked bioorganic constituents

It is unlikely that color had much influence on substrate choice, although we cannot completely dismiss this effect, because similarly colored substrates were unavailable. However, red king crab glaucothoe settle on black or white airstones with no particular preference, and tests on stage C5 to $\mathrm{C} 9$ crabs $(6$ to $12 \mathrm{~mm}$ length) have shown no statistical preference for black versus white gravel (B.G.S. unpubl. data). Glaucothoe probably did not select substrates to match their pale translucent body color, which made them difficult to see on any substrate, especially under the low light conditions of this study.

YOY red king crab occur naturally on substrates which are coarse or hard and have abundant live epifaunal cover; they probably settle and metamorphose on these substrates. In Kachemak Bay, Alaska, USA, only $2 \%$ of YOY king crab were captured from fine substrates (silt, sand, or fine granules) with a bottom skimmer and suction dredge, whereas $98 \%$ were captured from course substrates (pebbles, cobble, boulders, or shell debris) covered with branched epifauna such as hydroids and bryozoans (Sundberg \& Clausen 1977). Sundberg \& Clausen (1977) concluded that postlarval red king crab do not occupy fine substrates, and that 'the type and density of epifaunal cover appears to influence the distribution of postlarval crab.' Our observations agree well with the results of their study. In the Bering Sea, YOY red king crab have been found almost exclusively among epifauna (hydroids, bryozoa, polychaete and mussel colonies) attached to dispersed hard substrates such as gravel or shell debris (McMurray et al. 1986, Stevens \& Macintosh 1991). Babcock et al. (1988) found that YOY red king crab preferred bryozoan and hydroid assemblages when given a choice of several different substrates in the laboratory. This preference of glaucothoe for structured habitats with epifauna partially explains the success of artificial collectors developed by Blau \& Byersdorfer (1994), which have proved extremely effective for collecting red king crab glaucothoe and holding YOY instars.

Red king crab glaucothoe which did not settle on a preferred substrate exhibited strong diurnal swimming behavior. This behavior is the reverse of most planktonic organisms, and persists from the larval phase. In nature, red king crab zoeae ascend in the water column during daylight for feeding, and descend at night (Shirley \& Shirley 1987, 1989a). A number of other crab species exhibit some type of endogenous rhythmic swimming behavior, although it is often altered by exogenous factors or entrainment. Blue crab megalopae exhibit diurnal vertical migration in offshore water (Forward et al. 1997), but the behavior is suppressed by exogenous factors including high light intensity (Forward \& Rittschoff 1994) in estuarine waters, so that megalopae are only found there during nighttime flood tides (Tankersley \& Forward 1994). Swimming by blue crab megalopae increases with increasing pressure and salinity (which occur during flood tides in estuaries), but decreases with increased light level (Tankersley et al 1995). Megalopae of the shore crab Carcinus maenas exhibit endogenous swimming rhythms coinciding with ebb tides in the laboratory, but appear in ocean surface waters during 
flood tides, probably due to the influence of exogenous factors (Zeng \& Naylor 1996). Zoea and megalopae of the mud crab Rithropanopeus harrisii raised in the laboratory have a weak diurnal vertical migration, but wild-caught larvae exhibit strong tidally synchronized swimming behavior (Cronin \& Forward 1979), probably as a result of entrainment. For most of the species cited above, tidally synchronized swimming behavior has adaptive significance because it allows them to be transported up-estuary in surface waters during flood tides, toward parent stocks and nursery areas.

While swimming behavior of red king crab glaucothoe in the lab was clearly diurnal, behavior in the natural environment could be different. In the experimental aquaria, nocturnal cessation of swimming caused glaucothoe to descend only $18 \mathrm{~cm}$ to the substrate. In the open ocean glaucothoe would sink greater distances, and might resume swimming in deeper water. During their non-swimming phase, red king crab glaucothoe were inactive on the bottom of the tank, a behavior also exhibited by Carcinus maenas (Zeng \& Naylor 1996) and Callinectes sapidus (Forward et al. 1997). Red king crab are usually not found in estuaries, though some occur in coastal fjords, and most juveniles settle subtidally. Therefore, they would not necessarily benefit from tidally synchronized swimming and transport. Our glaucothoe did not appear to exhibit any tidal behavior, consistent with the fact that they were all raised in the lab and had never experienced tidal cycles.

Diurnal vertical migration allows feeding zoeae to avoid nocturnal predators, but probably has a different function in the glaucothoe stage. Several lines of evidence suggest that lithodid glaucothoe do not feed, including reduced and non-functional mouthparts (Sato \& Tanaka 1949, Hoffman 1968, Haynes 1982, Abrunhosa \& Kittaka 1997), identical survival of fed and unfed glaucothoe (J.K. unpubl. data), lack of food in the guts of fed glaucothoe ( $F$. Abrunhosa, Research Institute for Marine Biology, Onnemoto 168, Nemuro, Hokkaido, Japan, pers comm., April 1996), and low consumption of food (Nakanishi 1987, 1988). Lack of feeding provides glaucothoe the flexibility to continue a planktonic lifestyle while searching for suitable habitat, or to settle immediately once it has been found, without dietary consequences. This is especially important for juvenile red king crabs, because the type of live habitat they prefer occurs over a large geographic area, but is scarce in terms of relative surface area. In fact, feeding can be a distraction to invertebrate larvae seeking settlement sites, because '[f]eeding larvae may exploit cues common to most sites within their wide range of dispersal...', and as a result can make '... disastrously poor choices...' for settlement (Strathmann 1985). However, lack of feeding may limit the ability of postlarvae to delay metamorphosis (Pechenik 1990).

Swimming behavior in the sand-only aquarium increased when the cover was removed for $2 \mathrm{~d}$ during the diurnal study (Days 11 and 12), whereas swimming in the gravel, mesh, and mixed-substrate aquaria did not appear to be affected by cover removal. Mortality of glaucothoe was not caused by exposure to synthetic mesh, so was probably due to local oxygen depletion. Airstones in the tanks circulated water above the mesh, but water within the mesh at the bottom of the tank may have been trapped, and not circulated freely. After settlement on the mesh substrate, glaucothoe 'burrowed in' and remained virtually immobile; those in the mesh-only tank showed no movement after Day 12. These conditions may have caused glaucothoe deep within the mesh to deplete the oxygen from their immediate vicinity after 2 to $3 \mathrm{~d}$. Water exchanges, and removal of the substrates at $2 \mathrm{~d}$ intervals were adequate for good survival, whereas high mortality occurred on the first occasion (Day 13) when water had not been changed for $3 \mathrm{~d}$. However, high mortality of glaucothoe on Day 13 does not alter the main conclusion, that settlement on mesh was rapid and essentially complete by Day 5.

Development of red king crab from zoea stage 1 (Z1) to $\mathrm{C} 1$ requires 46 to $48 \mathrm{~d}$ at $8^{\circ} \mathrm{C}$ (a total of 376 degreedays), and about $33 \mathrm{~d}$ at $13^{\circ} \mathrm{C}$ (or 429 degree-days; Nakanishi \& Naryu 1981, Nakanishi 1987). Total development in the present study required $27 \mathrm{~d}$ from $\mathrm{Z} 1$ to $\mathrm{G}$ (at $8^{\circ} \mathrm{C}$ ), and $17 \mathrm{~d}$ from $\mathrm{G}$ to $\mathrm{C} 1$ (at $10.6^{\circ} \mathrm{C}$ ), for a total of 44 d and 396 degree-days. Kurata (1960) estimated complete development to require 460 degreedays. However, evidence cited above concerning substrate effects on TTM suggest that these development rates may be limited to laboratory environments, and that actual TTM in the field may be much shorter in the presence of specific substrate cues.

The results of this experiment help explain observed temporal and spatial recruitment patterns of red king crab. First, open sand bottoms are poor substrates. Glaucothoe cannot grip such a substrate, and are easily disturbed. Since glaucothoe do not bury in the sand, their high 'pincushion' profile makes them particularly vulnerable to predation. Major declines in recruitment of juvenile red king crab in the Gulf of Alaska (Blau 1986) and the Bering Sea (Otto 1990) occurred in the late 1970 s, simultaneous with large increases in abundance of demersal fishes such as Pacific cod and rock sole, both of which are predators on red king crab (Livingston 1989), implicating fish predation as a major deterrent to recovery of red king crab populations. The ability of king crab glaucothoe to locate cryptic habitats, and actively avoid open sand, may be an adaptive response to high predation levels. Second, this study 
emphasizes the importance of structurally complex substrates with interstitial space (such as highly branched epifauna), as do studies of artificial collectors (Donaldson et al. 1992, Blau \& Byersdorfer 1994). Despite the scarcity of such substrates in nature, behavioral mechanisms may allow a large proportion of the settling population of red king crab glaucothoe to locate adequate substrate. In the Bering Sea, an important habitat for YOY red king crab is bivalve shells with attached epifauna (particularly the stalked ascidian Boltenia sp.) (Stevens \& MacIntosh 1991). This habitat is extremely vulnerable to disturbance and removal by commercial fishing, due to entanglement of the ascidian stalks (which can reach $50 \mathrm{~cm}$ in length) in bottom trawls. Despite the importance of these habitats as refuges, and their vulnerability to alteration or removal by fishing practices, closure of a large portion of the Bering Sea to trawling has had little effect on recovery of red king crab populations (Armstrong et al. 1991). In view of the economic value of these crabs, more intensive study of their settlement behavior seems warranted. Important topics for future research include the effects of live substrates and of molt stage on settling behavior and timing of metamorphosis.

Acknowledgements. This manuscript benefitted from reviews by R. Otto, T. Shirley, S. F. Blau, and several anonymous reviewers. B. A. Johnson provided statistical advice. B.G.S. conducted all experiments and analysis, while J.K. provided träningy, equipmeni, ià space, and guidance.

\section{LITERATURE CITED}

Abello PC, Warman G, Naylor E (1997) Circatidal moulting rhythm in the shore crab Carcinus maenas. J Mar Biol Assoc UK 77:277-280

Abrunhosa FA, Kittaka J (1997) Functional morphology of mouthparts and foregut of the last zoea, glaucothoe and first juvenile of the king crabs Paralithodes camtschaticus, $P$. brevipes, and $P$. platypus. Fish Sci 63:923-930

Armstrong DA, Wainwright TC, Jensen GC, Dinnel PA, Andersen HB (1991) Taking refuge from bycatch issues: red king crab (Paralithodes camtschaticus) and traw] fisheries in the eastern Bering Sea. Can J Fish Aquat Sci 50: 1993-2000

Babcock MB, Brodersen CC, Rounds PA (1988) Habitat preference in juvenile red king crabs (Paralithodes camtschat ica). Am Zool 28(4):27A

Blau SF (1986) Recent declines of red king crab (Paralithodes camtschatica) populations and reproductive conditions around the Kodiak archipelago, Alaska. In: Jamieson G, Bourne $N$ (eds) North Pacific workshop on stock assessment and management of invertebrates Can Spec Publ Fish Aquat Sci 92:360-369

Blau SF, Byersdorfer SC (1994) Sausage-shaped artificial collector developed in Alaska to study young-of-the-year red king crabs. Bull Mar Sci 55:878-886

Brumbaugh RD, McConaugha JR (1995) Time-to-metamorphosis of blue crab Callinectes sapidus megalopae: effects of benthic macroalgae. Mar Ecol Prog Ser 129:113-118

Castro P (1978) Settlement and habitat selection in the larvae of Echinoecus pentagonus (A Milne Edwards), a brachyuran crab symbiotic with sea urchins. J Exp Mar Biol Ecol $34: 259-270$

Cronin T, Forward RB Jr (1979) Tidal vertical migration: an endogenous rhythm in estuarine crab larvae. Science 205: 1020-1022

Dew CB (1988) Behavioral ecology of podding red king crab, Paralithodes camtschatica. Can J Fish Aquat Sci 47 : 1944-1958

Dew CB, Cummıkey PA, Munk JE (1992) The behavioral ecology and spatial distribution of red king crab and other target species: Implications for sampling design and data treatment. Final Report to The Kodiak Island Borough. Available from National Marine Fisheries Service, Kodiak Laboratory, PO Box 1638, Kodiak, AK 99615

Donaldson WE, Byersdorfer S, Pengilly D, Blau SF (1992) Growth of red king crab, Paralithodes camtschaticus (Tilesius, 1815), in artificial habitat collectors at Kodiak, Alaska. J Shellfish Res 2(1):85-89

Forward RB Jr (1974) Negative phototaxis in crustacean larvae: possible functional significance. J Exp Mar Biol Ecol 16:11-17

Forward RB Jr (1989a) Depth regulation of larval marine decapod crustaceans: test of hypothesis. Mar Biol 102: $195-201$

Forward RB Jr (1989b) Behavioral responses of crustacean larvae to rates of salinity change. Biol Bull (Woods Hole) $176: 229-238$

Forward RB Jr (1990) Behavioral responses of crustacean larvae to rates of temperature change. Biol Bull 178:195-204

Forward RB Jr, DeVries MC, Rittschof D, Frankel DAZ. Bischoff JP, Fisher CM, Welch JM (1996) Effect of environmental cues on metamorphosis of the blue crab Callinectes sapidus. Mar Ecol Prog Ser 131:165-177

Forward RB Jr, Frankel DAZ, Rittschof D (1994) Molting of megalopae from the blue crab Callinectes sapidus: effects of offshore and estuarine cues. Mar Ecol Prog Ser 113:55-59

Forward RB Jr, Rittschoff D (1994) Photoresponses of crab megalopae in offshore and estuarine waters: implications for transport. J Exp Mar Biol Ecol 182:183-192

Forward RB Jr, Swanson J, Tankersley RA, Welch JM (1997) Endogenous swimming rhythms of blue crab, Callinectes sapidus, megalopae: effects of offshore and estuarine cues. Mar Biol 127:621-628

Forward RB Jr, Wellins CA, Busswell CU (1989) Behavioral responses of larvae of the crab Neopanope sayi to hydrostatic pressure. Mar Ecol Prog Ser 57:267-277

Freese JL, Babcock MM (1990) The utility of artificial substrate collection devices to determine time and location of red king crab (Paralithodes camtschaticus) glaucothoe settling in Auke Bay, Alaska. In: Baxter B (ed) Proceedings of the International Symposium on King and Tanner Crabs. Alaska Sea Grant College Program Report No. 90-04, University of Alaska, Fairbanks, p 119-130

Harms J (1992) Larval development and delayed metamorphosis in the hermit crab Clibanarius erythropus (Latreille) (Crustacea, Diogenidae). J Exp Mar Biol Ecol $156: 151-160$

Harvey AW (1993) Larval settlement and metamorphosis in the sand crab Emerita talpoida (Crustacea:Decapoda: Aromura). Mar Biol 117:575-581

Haynes E (1982) Description of larvae of the golden king crab, Lithodes aequispina, reared in the laboratory. Fish Bull $80(2): 305-313$

Herrnkind WF, Butler MJ IV (1986) Factors regulating postlarval settlement and juvenile microhabitat use by spiny lobsters Panulirus argus. Mar Ecol Prog Ser 34:23-30 
Hoffman EG (1968) Description of laboratory-reared larvae of Paralithodes platypus (Decapoda, Anomura, Lithodidae). $J$ Fish Res Bd Can 25(3):439-455

Jensen GC (1989) Gregarious settlement by megalopae of the porcelain crabs Petrolisthes cinctipes (Randall) and $P$. eriomerus Stimpson. J Exp Nar Biol Ecol 131:223-231

Kurata $H(1960)$ Studies on the larvae and postlarvae of Paralithodes camtschatica. III. The influence of temperature and salinity on the survival and growth of the larvae. Bull Hokkaido Reg Fish Res Lab 21:9-14

Lipcius RN, Olmi EJ IIl, Van Montfrans J (1990) Planktonic availability, molt stage, and settlement of blue crab postlarvae. Mar Ecol Prog Ser 58:235-242

Livingston P (1989) Interannual trends in Pacific cod, Gadus macrocephalus, predation on three commercially important crab species in the eastern Bering Sea. Fish Bull 87:807-827

McMurray $G$, Vogel A.H, Fishman PA, Armstrong DA, Jewett SC (1986) Distribution of larval and juvenile red king crabs (Paralithodes camtschatica) in Bristol Bay. US Department of Commerce, NOAA, OCSEAP, Final Report 53:267-477. OCSEAP Alaska Office, Anchorage

Nakanishi T (1981) The effect of temperature on growth, Survival, and oxygen consumption of larvae and post-larvae of Paralithodes brevipes (Decapoda: Anomura). Bull Jpn Sea Reg Fish Res Lab 32:49-56

Nakanishi T (1987) Rearing condition of eggs, larvae, and postlarvae of king crab. Bull Jpn Sea Reg Fish Res Lab 37: $57-161$

Nakanishi T (1988) Effects of environment on seedlings of the king crab, Paralithodes camtschatica. In: Sinderman CJ (ed) Environmental quality and aquaculture systems. NOAA Tech Rep NMFS 69, October 1988, Seattle, p 25-35

Nakanishi T, Naryu M (1981) Some aspects of large-scale rearing of larvae and postlarvae of the king crab (Paralithodes camtschatica). Bull Jpn Sea Reg Fish Res Lab 32:39-47

O'Connor NJ, Judge ML (1997) Flexibility in timing of molting of fiddler crab megalopae: evidence from in situ manipulation of cues. Mar Ecol Prog Ser 146:55-60

Otto RS (1990) An overview of eastern Bering Sea king and Tanner crab fisheries. In: Baxter B (ed) Proceedings of the International Symposium on King and Tanner Crabs. Alaska Sea Grant College Program Report No. 90-04, University of Alaska, Fairbanks, p 9-26

Paul AJ, Paul JM (1990) Growth of stage I king crab larvae of Paralithodes camtschatica (Tilesius) (Decapoda: Lithodidae) in natural communities. J Crustac: Biol 10(2):175-183

Paul AJ, Paul JM, Coyle KO (1989) Energy sources for first feeding zoeae of king crab Paralithodes camtschatica (Tilesius) (Decapoda, Lithodidae). J Exp Mar Biol Ecol 130:55-69

Pechenik JA (1990) Delayed metamorphosis by larvae of benthic marine invertebrates: Does it occur? Is there a price to pay? Ophelia 32:63-94

Powell GC, Nickerson RB (1965) Aggregations among juvenile king crabs (Paralithodes camtschatica, Tilesius) Kodiak, Alaska. Anim Behav 13(2-3):374-380

Sato S, Tanaka S (1949) Study on the larval. stage of Paralithodes camtschatica (Tilesius) I. About morphological research. Hokkaido Fish Exp Station, Res Rep No. 1 (in Japanese, with English translation)

Scheltema RS (1974) Biological interactions determining larval settlement of marine invertebrates. Thalass Jugoslav 10:263-296

Shirley SM, Shirley TC (1988) Behavior of red king crab larvae: phototaxis, geotaxis and rheotaxis. Mar Behav Physiol 13:369-388

Shirley SM, Shirley TC (1989a) Diel feeding periodicity of larvae of the red king crab, Paralithodes camtschatica. In:
Baxter B (ed) Proceedings of the International Symposium on King and Tanner Crabs. Alaska Sea Grant College Program. Report No. 90-04, University of Alaska, Fairbanks, p 233-244

Shirley SM, Shirley TC (1989b) Interannual variability in density, timing, and survival of Alaskan red king crab Paralithodes camtschatica larvae. Mar Ecol Prog Ser 54:51-59

Shirley TC, Shirley SM (1987) Diel vertical migration of Alaskan red king crab zoeae. (Abstract only.) Am Zool 27(4):542

Shirley TC. Shirley SM (1989c) Temperature and salinity tolerances and preferences of red king crab larvae. Mar Behav Physiol 16:19-30

Stevens BG, MacIntosh RA (1991) Cruise Results Supplement OH-91-1 (Ocean Hope 3). A survey of juvenile red king crabs with dredge and beam trawl, in Bristol Bay, Alaska Available from National Marine Fisheries Service, Kodiak Laboratory, PO Box 1638, Kodiak, AK 99615

Strathmann RR (1985) Feeding and nonfeeding larval development and life-history evolution in marine invertebrates. Annu Rev Ecol Syst 16:339-361

Sulkin SD, Von Heukelem W, Kelly P, Von Heukelem L (1980) The behavorial basis of larval recruitment in the crab Callinectes sapidus Rathbun: a laboratory investigation of ontogenetic changes in geotaxis and barokinesis. Biol Bull (Woods Hole) 159:402-417

Sundberg KA, Clausen D (1977) Post-larval king crab (Paralithodes camtschatica) in Kachemak Bay, Lower Cook Inlet, Alaska, 1976. In Traskey LL, Flagg LB, Burbank DC (eds) Environmental Studies of Kachemak Bay and Lower Cook Inlet. Vol 5:1-36. Alaska Dept of Fish and Game, Anchorage

Tankersley RA, Forward RB Jr (1994) Endogenous swimming rhythms in estuarine crab megalopae: implications for flood-tide transport. Mar Biol 118:415-423

Tankersley RA, McKelvey LM, Forward RB Ir (1995) Responses of estuarine crab megalopae to pressure, salinity, and light: implications for flood-tide transport. Mar Biol 1.22:391-400

Tyler AV, Kruse GH (1996) Conceptual modeling of brood strength of red king crabs in the Bristol Bay region of the Bering Sea. In: Baxter B (ed) Proceedings of the International Symposium on Biology, Management, and Economics of Crabs from High Latitude Habitats. University of Alaska Sea Grant Report No. 96-02, Fairbanks, p 511-544

Van Montfrans J, Peery CA, Orth RJ (1990) Daily, monthly, and annual settlement patterns by Callinectes sapidus and Neopanope sayi megalopae on artificial collectors deployed in the York River, Virgina: 1985-1.988. Bull Mar Sci 46(1):214-229

Wahle RA, Steneck RS (1991) Recruitment habitats and nursery grounds of the American lobster, Homarus americanus a demographic bottleneck? Mar Ecol Prog Ser 69:231-243

Weber JC, Epifanio CE (1996) Response of mud crab (Panopeus herbstil) megalopae to cues from adult habitat Mar Biol 126:655-661

Wolcott DL, De Vries MC (1994) Offshore megalopae of Callinectes sapidus: depth of collection, molt stage, and response to estuanne cues. Mar Ecol Prog Ser 109:157-163

Zar JH (1984) Biostatistical analysis, 2nd edn. Prentice Hall, Englewood Cliffs

Zeng C, Naylor E (1996) Occurrence in coastal waters and endogenous tidal swimming rhythms of late megalopae of the shore crab Carcinus maenas: implications for onshore recruitment. Mar Ecol Prog Ser 136:69-79

Zeng C, Naylor E, Abello P (1997) Endogenous control of timing of metamorphosis in megalopae of the shore crab Carcinus maenas. Mar Biol 128:299-305 